(C) The Author(s), 2021. Published by Cambridge University Press on behalf of the Arizona Board of Regents on behalf of the University of Arizona. This is an Open Access article, distributed under the terms of the Creative Commons Attribution licence (http://creativecommons.org/licenses/by/4.0/), which permits unrestricted re-use, distribution, and reproduction in any medium, provided the original work is properly cited.

\title{
MILLET CONSUMPTION IN SIBERIA PRIOR TO MID-SECOND MILLENNIUM BC? A REVIEW OF RECENT DEVELOPMENTS
}

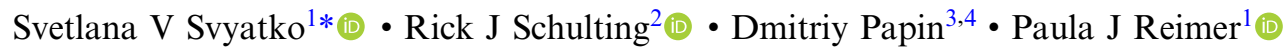 \\ ${ }^{1}$ Queen's University Belfast, ${ }^{14}$ Chrono Centre for Climate, the Environment, and Chronology, Belfast BT7 1NN UK \\ ${ }^{2}$ University of Oxford, School of Archaeology, 1 South Parks Road, Oxford, UK \\ ${ }^{3}$ Altay State University, Barnaul Laboratory of Archaeology and Ethnography of South Siberia, Barnaul, Russia \\ ${ }^{4}$ Siberian Branch of the Russian Academy of Sciences, Institute of Archaeology and Ethnography, Novosibirsk, Russia
}

\begin{abstract}
In this paper we discuss recent developments in documenting the spread of millet across the Eurasian steppes. We emphasize that, despite a recent proposal that millet consumption in southern Siberia can be attributed to the Early Bronze Age (i.e., the late third to early second millennium BC), at present there are no direct data for southern Siberia indicating the consumption of millet prior to the Late Bronze Age, from the 14th century BC. We also present in full the combined stable isotope and ${ }^{14} \mathrm{C}$ datasets from the Minusinsk Basin to support this conclusion.
\end{abstract}

KEYWORDS: Bronze Age, millet, Minusinsk Basin, radiocarbon dating, stable isotopes.

\section{INTRODUCTION}

Two of the major themes of stable isotopic research on the Eurasian steppes have involved investigating and documenting of the spread of millet (Svyatko et al. 2013; Motuzaite Matuzeviciute et al. 2015) and the extent of freshwater fish consumption (Privat et al. 2007; Schulting et al. 2014, 2015; Shishlina et al. 2012, 2014, 2018; Svyatko et al. 2015, 2017a). While it began with individual sites and groups of prehistoric people, this research has also been targeting more general issues such as adoption of major economic practices and documenting changes in subsistence patterns over time and space (Svyatko et al. 2013; Motuzaite Matuzeviciute et al. 2016). Most recently, there have been meta-analyses addressing various aspects of prehistoric life across the region, such as the transmission of domesticated cereals and the emergence of complex trans-regional political networks (Ventresca Miller and Makarewicz 2019).

While the role of freshwater reservoir effects continues to be debated, stable carbon isotope $\left({ }^{13} \mathrm{C}\right)$ analysis of human and faunal remains, especially when combined with radiocarbon $\left({ }^{14} \mathrm{C}\right)$ dating, has proven very successful in tracing the spread and use of millet. This is because millets (Panicum miliaceum and Setaria italica) are the only plausible candidates for a significant increase in consumption of $\mathrm{C}_{4}$ plants on the Eurasian steppes, whether directly or through foddered animals, and thus are relatively easily traced by $\delta^{13} \mathrm{C}$ values in human bone collagen. Obviously, ${ }^{14} \mathrm{C}$ dating of samples which demonstrate a clear $\mathrm{C}_{4}$ (millet) signal is crucial for understanding this process. In this contribution, we present a brief overview of isotopic studies focusing on the chronology of isotopic evidence for millet on the central Eurasian steppes, specifically within the Minusinsk Basin, and reiterate its appearance in the Late Bronze Age, from the 14th century BC.

Thus far, the earliest isotopic evidence for significant millet consumption in eastern China has been attributed to the Neolithic period (6200-5500 cal BC, Xiaojingshan and Yuezhuang sites; $\mathrm{Hu}$ et al. 2008, 2009), and in western China (Xinjiang) to the Bronze and Early Iron Age (from

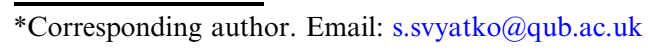


2000 BC, Wang et al. 2016, 2019; Qu et al. 2018; also summarized in Hu 2018). By ca. 2700 cal $\mathrm{BC}$, millet was used as fodder for domesticated stock in Dzhungar Alatau (southeastern Kazakhstan; Hermes et al. 2019). By the 17th-16th centuries BC millet consumption is isotopically recorded in southern Kazakhstan (Motuzaite Matuzeviciute et al. 2015), and by the final Bronze Age in central Kazakhstan (Lightfoot et al. 2015). To the northeast of this, in southern Siberia, millet apparently arrived in the Minusinsk Basin only during the 14th century BC (Svyatko et al. 2013), and by the 6th-7th centuries BC it is isotopically detected in the Tuva region (Murphy et al. 2013), though this is unlikely to mark their earliest appearance there. That said, clear isotopic evidence of significant millet consumption in Mongolia is also late, being mainly found from the 8th century BC (Wilkin et al. 2020).

In a recent synthesis, Ventresca Miller and Makarewicz (2019) propose that millet consumption in southern Siberia can be attributed to a much earlier period, namely, the late third to early second millennium BC (Early Bronze Age). This requires some discussion, as this conclusion, being a critical point for the perception of the history (economy, migrations, and cultural contacts) of southern Siberian populations, is inconsistent with the associated isotopic, paleobotanical and archaeological studies in the region. Their paper presents a meta-analysis of the existing stable isotope and paleobotanical data for the timing and spread of various cereals across a number of regions of the Eurasian steppe. The authors attempt not only to summarize the archaeological data, but also to demonstrate the use of cereals in regions which were previously considered to have been purely pastoral in terms of economy. This is particularly important for the Bronze Age archaeological complexes of the western and southern parts of Siberia, which have been traditionally seen as following a pastoral way of life (Gryaznov 1969).

As with any meta-analysis, there is a strong reliance on previously available data. Our main purpose in this brief paper is to correct a misunderstanding regarding the appearance of millet in southern Siberia at the end of the 3rd millennium BC, as this relies on a number of human stable carbon isotope $\left(\delta^{13} \mathrm{C}\right)$ values misattributed chronologically. Addressing one of the key regions of southern Siberia, the Minusinsk Basin, Ventresca Miller and Makarewicz (2019: p. e1) conclude that "low-level consumption of millet [was] possibly taking place in the Minusinsk Basin perhaps as early as the late third millennium cal BC" citing Svyatko et al. (2007) in fig. 4 and table S5 as the source for the first millet signal in the Afanasyevo and Okunevo populations. In particular, they show two "Afanasyevo" and one "Okunevo" individuals demonstrating high $\delta^{13} \mathrm{C}$ values (i.e., $>-17 \%$ ) that, in this region, are associated with consumption of the $\mathrm{C}_{4}$ plant millet. The authors conclude that "in the absence of radiocarbon determinations from human individuals analyzed for carbon and nitrogen isotopes, some individuals in the EBA group could date to as late as c. $2000 \mathrm{cal}$ BC", and that "low-level millet consumption by hunter-gatherer populations in the ES [Eurasian Steppe] may have taken place in the Early Bronze Age (EBA) sometime during the late third to early second millennium cal BC" (Ventresca Miller and Makarewicz 2019: p. e5). If true, this would present a very different picture of the transmission of millet into the region.

The paper cited, Svyatko et al. (2007), was one of our first reports at an early stage of our research in the area, presenting preliminary stable isotope results for the Bronze to Early Iron Age populations of the Minusinsk Basin for the proceedings of the 2007 Annual Conference of the Association for Environmental Archaeology (Poznań, Poland). Cultural attributions were based on archaeological evidence. Subsequent research, however, 
demonstrated that the three supposedly early individuals showing a "millet signal" in fact dated to the later Karasuk (Late Bronze Age), Tagar (Early Iron Age) and medieval periods. The ${ }^{14} \mathrm{C}$ dates were reported (Svyatko et al. 2009; samples UBA-7902, UBA-7904 and UBA-7920), as a part of an extensive, targeted dating program involving 88 humans from the Minusinsk Basin, previously analysed isotopically. This exercise showed that the first clear "millet signal" $\left(\delta^{13} \mathrm{C}\right.$ $>-17 \%$ ) in the Minusinsk Basin appeared in the 14th century BC, as shown in Svyatko et al. (2013, fig. 3). We recognize that there were issues in comparing the ${ }^{14} \mathrm{C}$ dates and stable isotope results directly in our previous publications, though our reporting of the minimum and maximum values for each archaeological period and complex clearly showed that there were no $\delta^{13} \mathrm{C}$ values above $-17.8 \%$ o for any period prior to the Karasuk culture (Svyatko et al. 2013: table 2). To avoid further misunderstandings, we present the full dataset here (Figure 1 and SI Table 1). Another important point to emphasize here is that even after the 14th century $\mathrm{BC}$, there was considerable variability in the consumption of millet, with some individuals showing little to no use, and this continued well into the Early Iron Age (cf. Murphy et al. 2013; Shishlina et al. 2016; Wilkin et al. 2020); similar observations have been made for central Kazakhstan (Lightfoot et al. 2015). We have previously addressed the possibility of a freshwater reservoir effect on the ${ }^{14} \mathrm{C}$ dates obtained (Svyatko et al. 2017a), and, while it remains a possibility, we do not think it would have a major impact on the date for the introduction of millet into the Minusinsk Basin.

Southern Siberia is one of the crucial regions of cultural genesis and interaction in the steppe zone; its importance for the Bronze and Early Iron Age of the Eurasian steppe belt has been continuously emphasized in the literature since the first expeditions by German scientists on Russian service (D.G. Messerschmidt, P.S. Pallas, W. Radloff) to the area in the 18th-19th centuries. For the 20th-15th centuries BC, this region and the adjacent southern part of West Siberia are represented by a number of autochthonous cultural complexes (Elunino and Okunevo) and those where bearers migrated from the west (Afanasyevo and Andronovo), as recently confirmed by ancient DNA (Allentoft et al. 2015). According to archaeological and archaeozoological data, they all practiced a primarily stock-rearing economy (Gryaznov 1969).

Despite the role of cereal cultivation in supplementing the pastoral economy of Bronze Age communities in the south of West Siberia being originally discussed in the 1930s, the first reliable evidence of grain consumption was recorded only for the Late Bronze Age, 14th9th centuries BC, in the Irmen Complex Milovanovo settlement where wheat impressions on pottery were found (Sidorov 1986). This was the period when the Andronovo Complex was replaced by new material culture (including bronze sickles possibly used for harvesting cereals, as well as mattocks and quernstones) seen in the Irmen and Karasuk complexes. Importantly, this was associated with increased contacts between the populations of southern Siberia and the Central Plains of China. Prior to this time, there is evidence for interactions only between the Afanasyevo or Okunevo complexes of southern Siberia and the Dzhungar Basin (e.g., Qiemu'erqieke cemetery; Jia and Betts 2010), and between Andronovo and Xinjiang, as summarized in Svyatko et al. (2013; see also Jia et al. 2017), both regions being part of the steppe world during the Bronze Age. The first connections between Siberia and China are only attributed to the Shang period (16th-11th centuries BC; Kuzmina 2007).

Isotopically, the appearance of millet in the Late Bronze Age cultural complexes of southern Siberia was first described in Svyatko et al. (2013), where it was placed in the 14th century BC. 


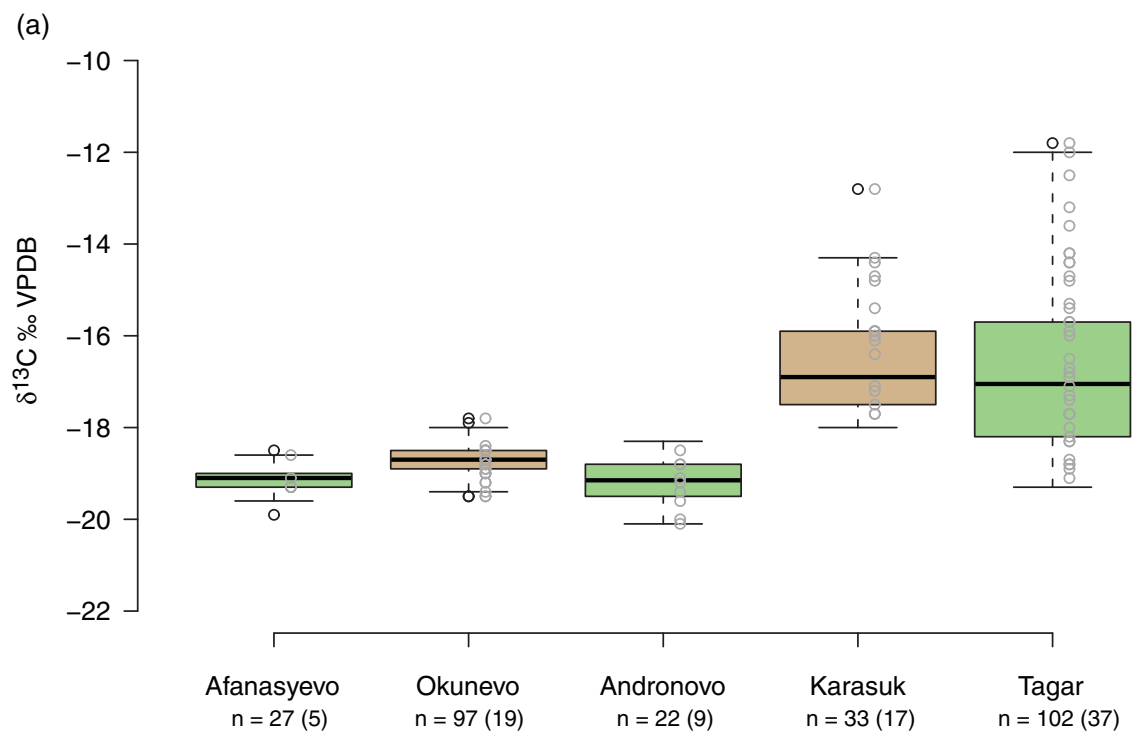

(b)

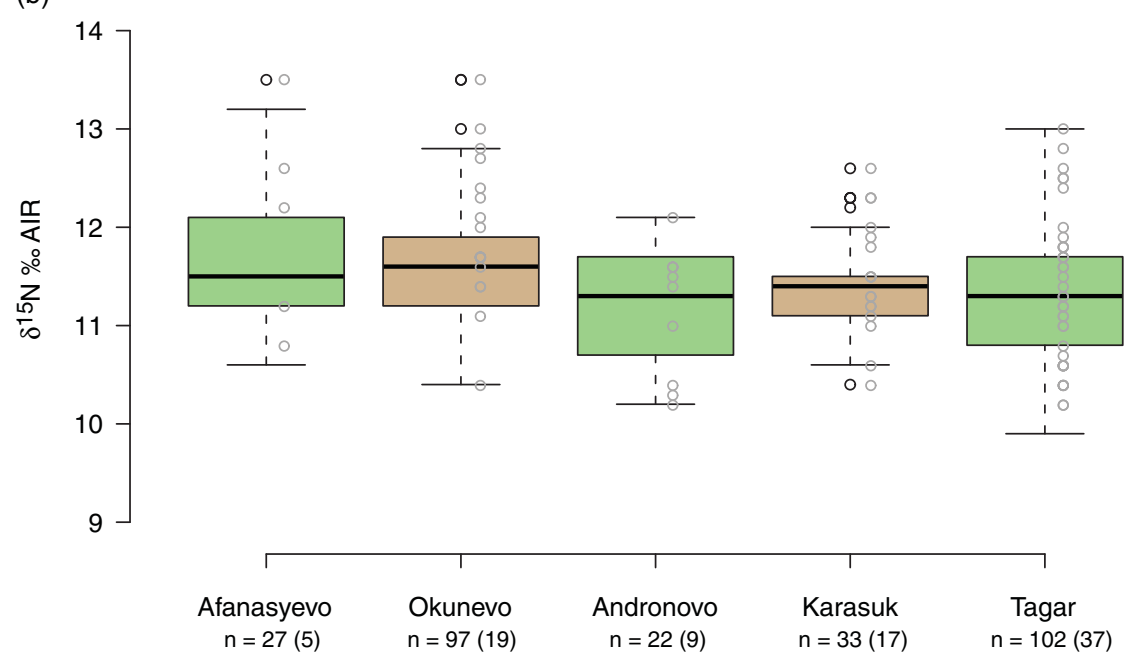

Figure 1 Boxplots showing (a) $\delta^{13} \mathrm{C}$ and (b) $\delta^{15} \mathrm{~N}$ values by culture. The lighter gray circles and number in brackets indicate individuals that have been directly ${ }^{14} \mathrm{C}$ dated.

That paper also discussed the context and implications of this conclusion, including intensified contacts between Karasuk groups and China, further detailed in later publications (Svyatko 2014, 2016). Subsequent recent research on earlier periods in the area and neighboring regions (Marchenko et al. 2015; Motuzaite Matuzeviciute et al. 2016; Svyatko et al. 2017c) has provided no evidence for any significant contribution of millet to human diet. However a $\mathrm{C}_{4}$ signal was detected for at least three 14th-13th centuries $\mathrm{BC}$ individuals out of 7 humans analysed from the Irmen Complex sites of Firsovo-14 and Plotinnaya in the upper $\mathrm{Ob}$ River Basin ca. $1500 \mathrm{~km}$ to the northwest of the Minusinsk Basin $\left(\delta^{13} \mathrm{C}=-16.4 \%\right.$, $-15.6 \%$ o, $-15.5 \%$ ), with more systematic millet consumption only from the 5 th century $\mathrm{BC}$ 
$\left(\delta^{13} \mathrm{C}=-18.2 \pm 4.9 \%\right.$, ranging from $-24.6 \%$ to $-14.1 \%$ for a group of 65 Early Iron Age individuals; Svyatko et al. 2017b; Papin and Svyatko 2018).

In sum, a small number of key datapoints cited by Ventresca Miller and Makarewicz (2019) are inaccurate regarding the timing of the appearance of significant consumption (i.e., clearly detectable isotopically) of $\mathrm{C}_{4}$ crops in southern Siberia. The presence of cereals-both wheat and millet - in the local diets has only been reliably recorded archaeologically and isotopically following the transition from Andronovo to Irmen and Karasuk cultural traditions. At present, there are no direct data for southern Siberia indicating the consumption of millet prior to the 14th century BC, at least 600 years later than suggested in Ventresca Miller and Makarewicz (2019). Beyond setting the record straight for a few stable isotope values, the issue is of wider relevance since it links in with larger discussions concerning the cultural exchanges and transmissions across the Eurasian steppe, particularly regarding links with China.

The 2nd millennium BC was a highly dynamic period in Eurasian prehistory, characterised by intensified East-West migrations and exchanges in material culture and ideas. This was the time of a dramatic increase in human population and settlements in China, a "revolutionary" development towards the emergence of Chinese civilization and the formation of early states. The latest research in key archaeological sites of the Inner Asian Mountain Corridor (Wang et al. 2019, 2020) demonstrates that during the 2nd millennium BC millets spread westward out of the Yellow River Basin to Xinjiang, southern Kazakhstan, Minusinsk Basin and Europe. This dynamic period apparently witnessed the first steps of formation of the so-called "Isotopic Millet Road" (Wang et al. 2019) which extended from North China to Central Asia (including Siberia). This was likely driven by increased East-West contacts, including resource transfer, warfare, marriage, migration, and the rise of the Xia and Shang dynasties. The Gansu Corridor is the most likely route by which millet ultimately arrived into the Minusinsk Basin in the mid-2nd millennium BC. Millets were already in use in southeast Gansu region in the 6th millennium BC (Dadiwan site, Barton et al. 2009) and in northwest Gansu by at least 2000 BC (Atahan et al. 2011; Ma et al. 2016; see summary in Liu et al. 2021). Interestingly, at around the same time as a millet signal is detected in the Minusinsk Basin at ca. $1400 \mathrm{BC}$, there appears to be a parallel decrease in $\delta^{13} \mathrm{C}$ values in Gansu, suggesting the reciprocal arrival of wheat there (Ma et al. 2016; see also Liu et al. 2021). Whether this can be linked to climate change as proposed by Ma et al. (2016) is a subject for further research. In any case, this was undoubtedly a major milestone in the development of the regional economy and the long-distance cultural exchanges that are at the heart of the Eurasian steppe.

Regardless of our remarks, the paper by Ventresca Miller and Makarewicz (2019) has important implications for the study of particular localities and ways of adoption of cereal cultivation traditions in the Eurasian steppe belt and represents a major contribution towards our understanding of the regional prehistoric economies and societies. Needless to say, only further research in particular areas, especially the ${ }^{14} \mathrm{C}$ dating of human and/or animal remains suggestive of millet consumption, and the remains of the crops themselves, will provide us with the precise chronology and pathways of the spread of millet in Siberia. 
SUPPLEMENTARY MATERIAL

To view supplementary material for this article, please visit https://doi.org/10.1017/RDC. 2021.53

\section{REFERENCES}

Allentoft ME, Sikora M, Sjögren KG, Rasmussen S, Rasmussen M, Stenderup J, Damgaard PB, Schroeder H, Ahlström T, Vinner L, et al. 2015. Population genomics of Bronze Age Eurasia. Nature 522:167-172.

Atahan P, Dodson J, Li X, Zhou X, Hu S, Bertuch F, Sun N. 2011. Subsistence and the isotopic signature of herding in the Bronze Age Hexi Corridor, NW Gansu, China. Journal of Archaeological Science 38(7):1747-1753.

Barton L, Newsome SD, Chen F-H, Wang H, Guilderson TP, Bettinger RL. 2009. Agricultural origins and the isotopic identity of domestication in northern China. Proceedings of the National Academy of Sciences 106(14):5523-5528.

Gryaznov MP. 1969. The ancient civilization of South Siberia. London: Barrie \& Rockliff, The Cresset Press.

Jia PW, Betts A. 2010. A reanalysis of the Qiemu'erqieke (Shamirshak) cemeteries, Xinjian, China. Journal of Indo-European Studies 38(3/4):1-43.

Jia PW, Betts A, Cong D, Jia X, Doumani Dupuy PN. 2017. Adunqiaolu: New evidence for the Andronovo in Xinjiang, China. Antiquity 91(357):621-639.

Kuzmina E. 2007. The origin of the Indo-Iranians. Leiden-Boston: Brill.

Hermes TR, Frachetti MD, Doumani Dupuy PN, Mar'yashev A, Nebel A, Makarewicz ChA. 2019. Early integration of pastoralism and millet cultivation in Bronze Age Eurasia. Proceeding of the Royal Society B 286(1910):20191273.

Hu Y, Wang S, Luan F, Wang C, Richards MP. 2008. Stable isotope analysis of humans from Xiaojingshan site: implications for understanding the origin of millet agriculture in China. Journal of Archaeological Science 35(11):2960-2965.

Hu YW, Luan FS, Wang SG, Wang CS, Richards MP. 2009. Preliminary attempt to distinguish the domesticated pigs from wild boars by the methods of carbon and nitrogen stable isotope analysis. Science in China Series D-Earth Sciences 52(1):85-92.

$\mathrm{Hu}$ Y. 2018. Thirty-four years of stable isotopic analyses of ancient skeletons in China: an overview, progress and prospects. Archaeometry 60(1):144-156.
Lightfoot E, Motuzaite-Matuzeviciute G, O'Connell TC, Kukushkin IA, Loman V, Varfolomeev V, Liu X, Jones MK. 2015. How "pastoral" is pastoralism? Dietary diversity in Bronze Age communities in the Central Kazakhstan Steppes. Archaeometry 57(S1):232-249.

Liu R, Pollard M, Schulting R, Rawson J. Liu C. 2021. Synthesis of stable isotopic data for human bone collagen: A study of the broad dietary patterns across ancient China. The Holocene 31(2):302-312.

Ma M, Dong G, Jia X, Wang H, Cui Y, Chen F. 2016. Dietary shift after 3600 cal yr BP and its influencing factors in northwestern China: evidence from stable isotopes. Quaternary Science Reviews 145:57-70.

Marchenko Z, Orlova L, Panov V, Zubova A, Molodin V, Pozdnyakova OA, Grishin AE, Uslamin E. 2015. Paleodiet, radiocarbon chronology, and the possibility of freshwater reservoir effect for Preobrazhenka 6 burial ground, Western Siberia: preliminary results. Radiocarbon 57(4):595-610.

Motuzaite Matuzeviciute G, Kiryushin YF, Rakhimzhanova SZ, Svyatko S, Tishkin AA, O'Connell TC. 2016. Climatic or dietary change? Stable isotope analysis of NeolithicBronze Age populations from the Upper $\mathrm{Ob}$ and Tobol River basins. Holocene 26(10):17111721.

Motuzaite Matuzeviciute G, Lightfoot E, O'Connell TC, Voyakin D, Liu X, Loman V, Svyatko S, Usmanova E, Jones MK. 2015. The extent of cereal cultivation among the Bronze Age to Turkic period societies of Kazakhstan determined using stable isotope analysis of bone collagen. Journal of Archaeological Science 59:23-34.

Murphy EM, Schulting RJ, Beer N, Kasparov A, Pshenitsyna M. 2013. Iron Age pastoral nomadism and agriculture in the eastern Eurasian steppe: implications from dental palaeopathology and stable carbon and nitrogen isotopes. Journal of Archaeological Science 40(5):2547-2560.

Papin DV, Svyatko SV. 2018. The problem of emergence of agriculture in the Upper $\mathrm{Ob}$ region based on data from archaeology and isotope analysis. Theory and Practice of Archaeological Research 4(24):20-25. In Russian with English abstract. 
Privat KL, O'Connell TC, Hedges REM. 2007. The distinction between freshwater- and terrestrialbased diets: methodological concerns and archaeological applications of sulphur stable isotope analysis. Journal of Archaeological Science 34(8):1197-1204.

Qu Y, Hu Y, Rao H, Abuduresule I, Li W, Hu X, Jiang H, Wang C, Yang Y. 2018. Diverse lifestyles and populations in the Xiaohe culture of the Lop Nur region, Xinjiang, China. Archaeological and Anthropological Sciences 10:2005-2014.

Schulting RJ, Bronk Ramsey C, Bazaliiskii VI, Weber A. 2015. Highly variable freshwater reservoir effects found along the Upper Lena watershed, Cis-Baikal, Southeast Siberia. Radiocarbon 57(4):581-593.

Schulting R, Ramsey CB, Bazaliiskii VI, Goriunova OI, Weber A. 2014. Freshwater reservoir offsets investigated through paired human-faunal ${ }^{14} \mathrm{C}$ dating and stable carbon and nitrogen isotope analysis at Lake Baikal, Siberia. Radiocarbon 56(3):991-1008.

Shishlina N, Zazovskaya E, van der Plicht J, Sevastyanov EV. 2012. Isotopes, plants, and reservoir effects: case study from the Caspian Steppe Bronze Age. Radiocarbon 54(3-4):74960.

Shishlina N, Sevastyanov V, Zazovskaya E, van der Plicht J. 2014. Reservoir effect of archaeological samples from Steppe Bronze Age Cultures in Southern Russia. Radiocarbon 56(2):767-78.

Shishlina N, Pankova S, Sevastyanov V, Kuznetsova O, Demidenko Y. 2016. Pastoralists and mobility in the Oglakhty cemetery of southern Siberia: New evidence from stable isotopes. Antiquity 90(351):679-694.

Shishlina NI, van der Plicht J, Turetsky MA. 2018. The Lebyazhinka burial ground (Middle Volga Region, Russia): new ${ }^{14} \mathrm{C}$ dates and the reservoir effect. Radiocarbon 60(2):681-690.

Sidorov EA. 1986. On the crop agriculture of the Irmen Culture (based on materials of the foreststeppe Ob River Region. In: Molodin VI, resp. editor. Paleoeconomika Sibiri. Novosibirsk: Nauka Siberian branch. p. 54-66. In Russian.

Svyatko S. 2014. Dental palaeopathological analysis of the Eneolithic-Early Iron Age populations from the Minusinsk Basin, Southern Siberia: palaeodietary implications. Archaeology, Ethnology and Anthropology of Eurasia 2(58): 143-156.

Svyatko SV. 2016. Stable isotope analysis: outline of methodology and a review of studies in Siberia and the Eurasian Steppe. Archaeology, Ethnology and Anthropology of Eurasia 44(2):47-55.

Svyatko SV, Mallory JP, Murphy EM, Polyakov AV, Reimer PJ, Schulting RJ. 2009. New radiocarbon dates and a review of the chronology of prehistoric populations from the Minusinsk
Basin, Southern Siberia, Russia. Radiocarbon 51(1):243-273.

Svyatko SV, Mertz IV, Reimer PJ. 2015. Freshwater reservoir effect on redating of Eurasian Steppe Cultures: First results for Eneolithic and Early Bronze Age Northeast Kazakhstan. Radiocarbon 57(4):625-644.

Svyatko S, Murphy E, Schulting R, Mallory J. 2007. Environment, lifestyle and diet of prehistoric populations from the Minusinsk Basin, Southern Siberia, Russia. In: Makohonienko M, Makowiecki D, Czerniawska J, editors. Eurasian perspectives on environmental archaeology: the 2007 AEA Annual Conference. September 12-15, 2007. Poznań, Poland. Bogucki Wydawnictwo Naukowe. p. 139-142.

Svyatko SV, Schulting RJ, Mallory J, Murphy EM, Reimer PJ, Khartanovich VI, Chistov YK, Sablin MV. 2013. Stable isotope dietary analysis of prehistoric populations from the Minusinsk Basin, Southern Siberia, Russia: a new chronological framework for the introduction of millet to the eastern Eurasian steppe. Journal of Archaeological Science 40(11):3936-3945.

Svyatko SV, Schulting R, Poliakov A, Reimer PJ. 2017a. A lack of freshwater reservoir effects in human radiocarbon dates in the Eneolithic to Iron Age in the Minusinsk Basin. Archaeological and Anthropological Sciences 9(7):1379-1388.

Svyatko SV, Papin DV, Poshekhonova O. 2017b. Isotopic analysis of the prehistoric cultures of the Eurasian steppes and Siberia: Short overview and new data. In: Derevyanko AP, editor. Proceedings of V (XXI) All-Russian Archaeological Congress. V. 1. Barnaul: Altai State University. p. 927-928. In Russian.

Svyatko SV, Polyakov AV, Soenov VI, Stepanova NF, Reimer PJ, Ogle N, Tyurina EA, Grushin SP, Rykun MP. 2017c. Stable isotope palaeodietary analysis of the Early Bronze Age Afanasyevo Culture in the Altai Mountains, Southern Siberia. Journal of Archaeological Science: Reports 14:65-75.

Ventresca Miller AR, Makarewicz CA. 2019. Intensification in pastoralist cereal use coincides with the expansion of trans-regional networks in the Eurasian Steppe. Scientific Reports 9:8363.

Wang T, Fuller B, Wei D, Chang X, Hu Y. 2016. Investigating dietary patterns with stable isotope ratios of collagen and starch grain analysis of dental calculus at the Iron Age cemetery site of Heigouliang, Xinjiang, China. International Journal of Osteoarchaeology 26(4):693-704.

Wang T, Wei D, Chang X, Yu Z, Zhang X, Wang C, $\mathrm{Hu}$ Y, Fuller BT. 2019. Tianshanbeilu and the Isotopic Millet Road: reviewing the late Neolithic/Bronze Age radiation of human millet consumption from north China to Europe. National Science Review 6(5):1024-1039. 
Wang W, Liu Y, Duan F, Zhang J, Liu X, Reid REB, Zhang M, Dong W, Wang Y, Ruan Q, Li W, An C-B. 2020. A comprehensive investigation of Bronze Age human dietary strategies from different altitudinal environments in the Inner Asian Mountain Corridor. Journal of Archaeological Science 121:e105201.
Wilkin S, Ventresca Miller AR, Miller BK, Spengler RN, Taylor WTT, Fernandes R, Hagan RW, Bleasdale M, Zech J, Ulziibayar S, Myagmar E, Boivin N, Roberts P. 2020. Economic diversification supported the growth of Mongolia's nomadic empires. Scientific Reports 10(1):e3916. 